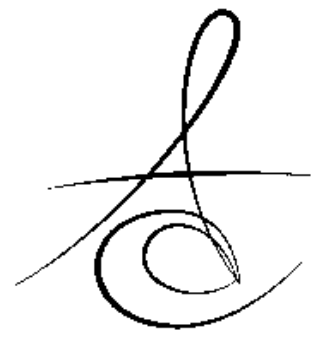

\title{
RESTORATİF DİŞ HEKİMLİĞİNDE OZON TEDAVİLERİ
}

\section{OZON THERAPIES IN RESTORATIVE DENTISTRY}

\section{Dt. Gizem BOZTAŞ*}

\author{
Prof. Dr. Hüma ÖMÜRLÜ*
}

Makale Kodu/Article code: 1402

Makale Gönderilme tarihi: 19.11.2013

Kabul Tarihi: 18.02.2014

\section{ÖZET}

Ozon stratosfer tabakasında bulunan, üç oksijen atomundan oluşan doğal bir gazdır. Ozon güçlü bir oksidan ve etkili bir antimikrobiyal ajandır. Bu nedenle yıllardır tıpta ve diş hekimliğinde kullanılmaktadır. Çeşitli çalışmalar ozonun; diş hekimliğinde; dental gereçlerin sterilizasyonunda, dental cerrahide, periodontal hastalıkların ve bazı oral patolojilerin tedavisinde, kök-kanal tedavisinde ve aktif çürüklerdeki bakteri miktarını azaltarak diş çürüğünün önlenmesinde kullanıldığını bildirmiştir. Son yıllarda yapılan bazı çalışmalar ozonun diş beyazlatmada da kullanılabileceğini bildirmiştir. Bu derlemenin amacı in vivo ve in vitro çalışmaları inceleyerek ozonun restoratif diş hekimliğinde kullanımını değerlendirmektir.

Anahtar kelimeler; ozon, restoratif diş hekimliği, çürükler, ağartma

\section{ABSTRACT}

Ozone is a natural gas that is composed of three oxygen atoms and found in stratosphere. It is a powerful oxidant and an efficient antimicrobial agent, therefore, it is used in medicine and dentistry for many years. Several studies have reported that, ozone is used in the sterilization of dental instuments, dental surgery, treatment of periodontal diseases and some oral pathologies, root-canal treatment, the prevention of tooth decay by reducing the bacterial count in active carious lesions in dentistry. Also, in recent years, some studies reported that ozon was used in tooth whitening. The aim of this review is to evaluate the usage of ozone in restorative dentistry by evolution in vivo and in vitro studies.

Keywords; Ozone, restorative dentistry, caries, bleaching

\section{GİRİŞ}

\section{Ozon ve Kimyasal Yapısı}

Ozon doğada kendiliğinden var olabilen, üç adet oksijen atomu içeren bir moleküldür. Bir adet oksijen atomu ile iki adet oksijen atomu içeren oksijen molekülünün kimyasal olarak birleşmesiyle oluşur. Oksijen ve ozon sürekli birbirlerine dönüşüm halindedirler. Bu dönüşümü sağlayan kimyasal reaksiyonlar, güneş ışığı kaynaklı yüksek frekanstaki UV ışınları tarafından katalize edilir ${ }^{1,2}$. Atmosferde ozon, gaz halinde; troposfer ve stratosfer tabakasında bulunur. Stratosfer tabakasında 1-10 ppm konsantrasyonunda doğal ozon bulunmaktadır ${ }^{2}$. Atmosfer dışından gelen B ve $C$ tipi ultraviyole radyasyon, stratosfer tabakasın- daki ozon tarafindan absorbe edilir. Stratosferde bulunan ozonun; stratosferin termal yapısında ve dünyanın ekolojik dengesi üzerinde kritik bir önemi vardır. Troposferde bulunan ozonun ise solunum yolu üzerinde toksik etkileri olduğu bildirilmiştir. Ozon; troposferde, arabaların egzoz gazları, oksijen ve güneş ışığını da içeren çok çeşitli reaksiyonlarla oluşur ${ }^{3}$. Ozonun başlıca endüstriyel kullanımları Tablo 1'de gösterilmiştir.

\section{Ozonun Tarihçesi}

Ozon, 1840 yllında Alman kimyacı Christian Frederick Schonbein tarafından, İsviçre, Basel Üniversitesi'nde keşfedilmiştir. Ancak ozon hakkında 1932 yılına kadar bilimsel araştırma yapılmamıştır ${ }^{4}$.

* Gazi Üniversitesi, Diş Hekimliği Fakültesi, Diş Hastalıkları ve Tedavisi Anabilim Dalı 
Tablo 1. Ozonun başlıca endüstriyel kullanımları ${ }^{3}$

\begin{tabular}{|c|c|c|}
\hline $\begin{array}{l}\text { Gıda } \\
\text { Endüstrisi }\end{array}$ & Kimyasal Endüstri & $\begin{array}{l}\text { Diğer Endüstriyel } \\
\text { Kullanımları }\end{array}$ \\
\hline $\begin{array}{l}\text { - Besin } \\
\text { koruması, } \\
\text {-Raf ömrünü } \\
\text { uzatmak, } \\
\text {-Ekipman } \\
\text { sterilizasyon } \\
\text { u, } \\
\text {-Bitkisel } \\
\text { yiyecek } \\
\text { atıklarının } \\
\text { değerlendiril } \\
\text { mesi, } \\
\text {-Soğuk } \\
\text { saklama } \\
\text { odalarındaki } \\
\text { yiyecekler } \\
\text { için } \\
\text { dezenfektan } \\
\text { ajanı olarak, } \\
\text {-Meyve } \\
\text { depolamada } \\
\text { küf ve maya } \\
\text { büyümesine } \\
\text { engel olmak } \\
\text { amacıyla. }\end{array}$ & $\begin{array}{l}\text {-Organik kimya } \\
\text { endüstrisinde oksidize } \\
\text { ajanı olarak, } \\
\text {-Un, kağıt hamuru, } \\
\text { nişasta ve şekerin } \\
\text { ağartımasında, } \\
\text { - Birtakım parfüm, } \\
\text { vanilinlerin } \\
\text { işlenmesinde, } \\
\text {-Vernik ve baskı } \\
\text { mürekkeplerinin hızlı } \\
\text { kurumasında, } \\
\text {-Nitrik asitten klorinin } \\
\text { çkarılmasında, } \\
\text {-Siyanür ve fenolün } \\
\text { oksidasyonunda, } \\
\text {-Likör ve odunun } \\
\text { yıllandırımasında. }\end{array}$ & $\begin{array}{l}\text { - İçme suyu ve havanın } \\
\text { dezenfeksiyonunda } \\
\text { dezenfektan ajanı } \\
\text { olarak, } \\
\text { - Endüstriyel atıkların } \\
\text { arıtılmasında, } \\
\text { - Uçucuların, havanın ve } \\
\text { kanalizasyon gazının } \\
\text { kokusunun } \\
\text { giderilmesinde, } \\
\text { - Bakteri öldürmede, } \\
\text { - Steroid hormonu } \\
\text { üretmede. }\end{array}$ \\
\hline
\end{tabular}

1. Dünya Savaşı sırasında ozon; Alman askeri birliklerinde travma sonrasında gazlı kangren, enfekte yaralar, hardal gazı yanıkları ve fistüllerin tedavisi için kullanılmıştır. Amerika'da 1880-1932 yılları arasında ozon alternatif ilaç olarak kabul edilmiştir ${ }^{5}$. 1930 yılında diş hekimi Dr. E.A. Fisch, ozunu (sıvı hali) çalışmalarında kullanan ilk doktordur. Ozonu, arkadaşı Dr.Erwin Pyre'a tanıtmıştır. Erwin Pyre, ozonu cerrahide kullanıp sonuçları 59. Alman Cerrahi Birliği Toplantısı'nda sunmuştur ${ }^{6}$. Bugün ise ozon tedavileri 16 ülkede geçerliliği kabul edilmiş tedavi yöntemleri arasında yer almaktadır ${ }^{2}$. Göz hastalıklarında, akut veya kronik viral, bakteriyel ve fungal enfeksiyonlarda, iskemik hastalıklarda, yaşa bağlı maküler dejenerasyonlarda, ortopedik hastalıklarda, deri, akciğer, böbrek, kan hastalıkları ve nörodejeneratif hastalıklarda kullanımı araştırılmaktadır ${ }^{5}$.

\section{Biyolojik Etkileri}

Ozonun insan vücudu üzerinde antimikrobiyal, bağışıklık sistemini uyarıcı, kan dolaşımını arttırıcı, biyosentetik, analjezik, detoksikasyon ve biyoenerjetik etkileri vardır?

Antimikrobiyal etki: Ozon, bakteri, mantar ve virüsler üzerinde sitotoksik bir etki gösterir. Ozonun antimikrobiyal etkisi; ikincil oksidan etkiler nedeniyle çift yönlü bağların ozonolizi sonucu hücrenin sitoplazmik zarına hasar vermesi şeklindedir. Bu etki mikrobiyal hücreler için non-spesifiktir ancak insan hücrelerinin yüksek düzeydeki oksit giderici yeteneğinden dolayı, insan hücrelerine zarar vermez. Ozon antibiyotiğe dirençli türlerde de çok etkilidir. Viral enfeksiyonlarda ozonun etkisi; enfekte hücrelerin peroksit ve reverse-kriptaz aktivitesindeki değişikliklere olan hassasiyetine dayanır., 10

Müller ${ }^{8}$ yaptığı bir çalışmada fotodinamik terapi ve ozon gazının antimikrobiyal etkinliğini değerlendirmiştir. Çalışmasında olgun oral biyofilmler kullanmıştır. Klorheksidin ve hipoklorit ile karşılaştırma yapmıştır. Sonuç olarak gaz halindeki ozonun ve fotodinamik terapinin karyojenik biyofilm üzerinde asgari düzeyde bir etkinliği olduğunu bildirmiştir.

Nagayoshi $^{9}$ ise bir çalışmasında ozonlanmış suyun dental plak üzerindeki etkinliğini incelemiştir. Ozonlanmış suyun oral gram pozitif-negatif mikroorganizmaları ve candida albicansları öldürmede etkili olduğunu bildirmiştir.

Yüksek konsantrasyonlu ozon bakterileri hızla öldürür ve diğer bakteri öldürme ajanlarından 1000 kat daha güçlü olabileceği bildirilmiştir ${ }^{10}$. Tedavilerde genellikle ortalama konsantrasyonda ozon kullanilır. (oksijen/ozon gaz karışımında mililitrede; 0,25 birim ozona, 99,75 birim oksijene karşılık gelir) ${ }^{10}$. Sıvı ya da gaz formdaki ozon, bakteri, fungus, protozoa ve virüslere karşı güçlü bir oksidandır ${ }^{14}$. Klorinin toksik yan etkilerine sahip değildir ve klorine göre daha düşük konsantrasyonlarda daha güçlü bir oksitleyicidir; ozonun bir molekülü, klorinin 3000 ila 10000 molekülüne eşittir, hastalık etkeni organizmaları 3500 kat daha hızı öldürebilir. ${ }^{10}$ Ozon birçok organik bileşiği oksidize edebilirve çok güçlü bir antiseptiktir ${ }^{11}$. Ozon uygulamasını takiben 4-6 hafta içinde tekrar- lanmış kolonizasyonlara rastlanmadığı bildirilmiştir ${ }^{12}$. Ozon sekiz saat içinde 0,05 ppm kadar verildiğinde toksik değildir. Ozon tedavisi boyunca oral kaviteye maksimum 0,01 ppm konsantrasyonunda ozon uygulanabilir. ${ }^{10,}$

Bağışıklık sistemini uyarıcı etkisi: Ozon hücresel ve hümoral bağışıklık sistemini etkiler. Immünokompetan hücrelerin ve immünoglobülinlerin sentezlenmelerinin artışını uyarır. Aynı zamanda makrofajların işlevlerini ve mikroorganizmaların fagositoza duyarlılığını arttırır. Ozon interlökin, lökotrien, pros- 
taglandin gibi iltihap giderici ve yara iyileştirici sitokinlerin sentezlenmelerine neden olur ${ }^{7}$. Düşük konsantrasyonlu ozon immünostimülatif etkiye neden olur. Ancak yüksek konsantrasyonlu ozon, immünodepresif etki yaratır ${ }^{10,11,13}$.

Antihipoksik etkisi: Ozon, dokulardaki oksijen basıncını ve kandaki oksijen dolaşımını arttırır. Bu hücresel metabolizma değişikliği aerobik işlemlerin aktivasyonu ve enerjetik kaynaklarının kullanımıyla sonuçlanır. Tekrarlayan düşük dozlu ozon uygulamasının etkili olduğu enzimler; super-oksit dismutazlar, katalazlar, dehidrojenazlar ve glütasyon peroksidazlardır. Bunlar organizmaları serbest radikallerin etkilerine karşı koruyan kompleks enzimatik sistemlerin bir parçasıdır. Aynı zamanda ozon eritrositlerin oksijen dolaşımını arttırmalarını sağlar. Dolaşımla ilgili bozuklukların tedavilerinde kullanılır ${ }^{7}$ Ozon, iltihaplı doku metabolizmasında oksijenasyonu arttırarak ve lokal iltihaplanmayı azaltarak iyileşmeyi sağlar. Eritrositlerin hücre zar yapısını değiştirerek ve negatif yüklerinin artmasına neden olarak elastikiyet kazanmalarını sağlar, kapillerden geçişini hızlandırır. Kanın dokulara oksijen bırakma yeteneğini sağlayan 2,3 DPG (difosfogliserat) miktarında artış meydana gelir. Bu da oksijenin iltihaplı dokuya geri dönmesine imkân tanır $^{10,13}$. Ozon, nitrözoksit gibi damar genişleticilerin salgılanmasına neden olur. Küçük atardamarların ve küçük damarların genişlemesinden de sorumludur ${ }^{7}, 10$. Kan dolaşımını arttırmak, anjiogenezi aktive etmek ve oksijen metabolizmasını uyarmak ozonun diğer önemli etkilerindendir. ${ }^{11,134}$

Biyosentetik etkisi: Protein sentezi mekanizmasını aktive eder. Hücrelerdeki ribozom ve mitokondri miktarını arttır. Hücre düzeyindeki bu değişiklikler; fonksiyonel aktiviteleri attırarak, doku ve organlardaki yenilenme potansiyelini uyarır ${ }^{7}$. Ozon molekülleri proteinlerin yapısında bulunan metionin, histidin, sistein gibi birçok biyomolekülü etkiler. Dental hastalıklarda önemli rolü olan bu biyomoleküllere ozonun etkisi sonucunda karyojenik bakteriler zarar görür, asidojenik bakteriler eliminasyona uğrar. Karyogenez sırasında asidojenik bakteriler tarafından üretilen en güçlü asit pirüvik asittir. Ozon pirüvik asiti dekarboksilasyona uğratarak asetik aside dönüştürür. Asetik asit üretimi ve plakta bulunan plak sıvısını tamponlayan diğer yüksek pH'a sahip asitler, başlangıç çürüklerinin remineralizasyonunu teşvik eder ${ }^{10}$.

\section{Ozon Toksisitesi}

Ozon, sekiz saat içinde 0,05 ppm kadar verildiğinde toksik değildir. Ozon tedavisi boyunca oral kaviteye maksimum 0,01 ppm konsantrasyonunda ozon uygulanabilir. Ozonun inhalasyonu pulmoner sistem ve diğer organlara zarar verebilir. Ozon terapisine bağlı komplikasyonlar nadir görülmektedir. (Her uygulamada 0,00007) bilinen yan etkiler öfori, üst solunum yolları irritasyonu, rinit, öksürük, baş ağrısı, bulantı, kusma, nefes kesilmesi, kan damarı gevşemesi, zayıf sirkülasyon ve kalp problemleridir. ${ }^{15}$ Ozon güçlü bir okside ajan olduğu için ozon ile temas eden materyallerin ozona dirençli cam, silikon, teflon gibi materyallerden yapılmış olması gerekir. Ozon tedavisi sırasında intoksikasyon gelişirse hasta yatar pozisyona getirilmeli ve $\mathrm{E}$ vitamini ve $\mathrm{N}$-asetilsistein ile tedavi edilmelidir ${ }^{16}$.

\section{Ozon Tedavisinin Kontrendikasyonları ${ }^{17}$}

- Hamilelik,

- Hipertiroidizm,

- Glukoz-6-fosfat-dehidrogenaz eksikliği,

- Ağır anemi,

- Ağır myestenia,

- Aktif hemoraji,

- Akut alkol intoksikasyonudur.

Ozon biyolojik özellikleri sayesinde diş hekimliğinde proflaksi amacıyla ve çok çeşitli hastalıkların tedavisinde kullanılabilir.

\section{Diş Hekimliğinde Ozonun Kullanım Alanlarrio}

PERİODONTOLOJİDE; gingivitis, periodontitis, periimplantitis, cerrahi yaralar ve proflakside,

ORAL PATOLOJILERDE; stomatitis, aftöz ülserasyon, kandidiazis, herpes enfeksiyonları,

ENDODONTIDE; kök-kanal tedavisinde, fistüllerde, abselerde,

CERRAHİDE; hemostaz, yara iyileşmesi, implantasyon, reimplantasyon, ekstraksiyonda,

PROTETİK Dİ̧̧ TEDAVİSi்; kron dezenfeksiyonu, parsiyel protezlerin alaşım kısımlarının dezenfeksiyonunda,

ORTODONTIDE; TME fonksiyon bozukluklarında, trismus, myoarthropati,

RESTORATİF DIŞ HEKİMLİĞİNDE; çürükler, dentin hassasiyeti, çatlak diş sendromu, ağartma, kavite dezenfeksiyonunda kullanılır. 
Diş hekimliğinde ozon SIVı ve gaz halinde kullanılır. ${ }^{17}$

\section{Ozonlu Sivilar}

Sıvı halde kullanılan ozon; ozonlu sular ve ozonlu yağlar şeklinde kullanılır.

Alman diş hekimi Fritz Kramer'e göre; SIVı haldeki ozonun diş hekimliğinde ${ }^{18}$;

- Güçlü dezenfektan olarak,

- Kanama kontrolünü sağlamak için,

- Kemik ve yumuşak doku yaralanmalarının temizliğinde,

- Yara içindeki lokal oksijen kaynağını arttırma ve iyileşmeyi hızlandırma amacıyla,

- Yara bölgesindeki sıcaklığı arttırma, dolayısıyla iyileşmede metabolik süreci hızlandırmak için, Ayrıca;

- Ağız çalkalama suyu olarak, (gingivitis, periodontitis, stomatitis)

- Sprey olarak enfekte alanların temizlenmesi, oral mukoza ve kavite dezenfeksiyonunda,

- Diş kavitelerinin temizlenmesi, kanal tedavisinde,

- Ağrılı gingivitis ve stomatitis tedavisinde kullanılır.

\section{Ozon Gazı}

Gaz halindeki ozon; sıklıkla restoratif diş hekimliğinde ve endodontide kullanılır. Gaz halindeki ozonun mikrobisid etkisi sıvı haldeki ozondan daha fazladır. Ancak kontrolsüz kullanımı da solunum yolunda olumsuz etkilere neden olabilir. Gaz ozonun topikal kullanımı sızdırmaz, vakumlu sistemler sayesinde ozonun olası yan etkilerini engeller ${ }^{16}$.

Gaz halindeki ozon çeşitli cihazlar yardımıyla uygulanır. Cihazlarda 4 farklı mekanizma kullanılır. ${ }^{10,16,18}$
1) Ultraviyole sistem,
2) Korona deşarj sistemi,
3) Elektromanyetik sistem,
4) Soğuk plazma sistemi,

Ultraviyole Sistem: Güneş kaynaklı UV ışınların oksijene temas etmesi ile doğal olarak ozon gazı oluşur $^{18}$.

Korona Deşarj Sistemi: Yüksek konsantrasyonda ozon üretir. Elektriksel ışınların oksijence zengin gaz karışımının içerisinden geçmesi ile oluşur. Elektriksel ışınlar üreten özel cihazlar vardır ${ }^{18}$.

Soğuk Plazma Sistemi: İyonik akımı indükleyen yüksek elektriklenmeye sahip, içerisinde halojen bulunan cam katot tüp içeren bir ünite mevcuttur. Bu ünite; içerisinden saf oksijenin geçtiği ikinci bir tüp ile sarılıdır. Bu ünite ise doğrudan akıma maruz kalmayan, metal iyon kirliliği nedeni ile oluşabilecek kontağı önleyen, tüm sisteme temel oluşturan ikinci elektrottur. Tüp içerisindeki plazmadaki akım oksijeni ozona dönüştürür. Bu yöntem medikal uygulamalarda rahatlıkla uygulanabilir. Diş hekimliğine özelleştirilmiş cihazların çoğunun çalışma mekanizması bu sisteme dayanır ${ }^{18}$.

Elektromanyetik sistem: Bu sistemde kristal cam tüp içerisinden oksijen akımı geçer. Bu tüpü içeriden ve dışarıdan geçen metal kablolar sarar. Yüksek frekansa sahip voltaj ile güçlü bir elektromanyetik alan oluşturulur. Sistemde oluşan sıcaklık için fan bulunmalıdır. Çünkü ozon sıcaklıktan etkilenir ${ }^{18}$.

Diş hekimliğine özelleştirilmiş cihazların çoğunun çalışma mekanizması soğuk plazma sistemine dayanmaktadır. Çeşitli firmalar, diş hekimliğinde kullanılan ozon cihazları geliştirmiştir; HEAL OZONE KAVO, Ozonytron MYMED ve Prozone W\&H bu tip cihazlara örnek olarak verilebilir.

\section{RESTORATİF DİŞ HEKİMLİĞİ VE OZON}

Ozon restoratif diş hekimliğinde biyolojik özelikleri nedeniyle çok çeşitli tedavilerde kullanılabilir. İnvaziv olmayan bir tedavi yöntemi olduğundan dolayı diş dokularının maksimum düzeyde korunmasını sağlar. Restoratif diş hekimliğinde ozonun kullanım alanları şunlardır;

- Çürüklerin önlenmesi ve çürük tedavileri,

- Dentin hipersensitivitesi,

- Çatlak diş sendromu,

- Ağartma tedavisidir.

\section{OZON ve DİŞ çÜRÜĞÜ TEDAVİLERİ}

Günümüzde çürük başlangıcı ve ilerleyişine ilişkin bilgiler artmıştır, en iyi tanımlama ile çürük; çok faktörlü, enfeksiyöz bir hastalıktır. Diş yüzeyindeki biyofilm tabakasında yer alan asidojenik, asidürik, karyojenik bakteriler (s.mutans, laktobasil) karbonhidrat fermentasyonu sonucunda metabolik ürün olarak asit oluştururlar. Bu asitler diş mine ve dentinini demineralize ederler. Buna karşın; tükürük ve remineralize edici solüsyonların mineralleri tekrar yerine koyma özellikleri sonucu sürekli devam eden demineralizasyon-remineralizasyon süreci ortaya çıkar. Bu 
süreçte demineralizasyona neden olan karyojenik olaylar ve tükürük gibi mineral tamponlayan, nötralizasyon ve remineralizasyon yapan etkiler denge durumundadır. Karyojenik etkiler sıklaşırsa; bu denge durumu değişir, demineralizasyon artar ve sonuç olarak diş çürümesi gerçekleşir. ${ }^{18,-20}$

Diş hekimleri çürüğün önlenmesi ve tedavisinde çeşitli girişimsel (drill-fill) ve girişimsel olmayan tedaviler kullanmaktadır ${ }^{19}$.

\section{Girişimsel Olmayan Tedavi Yöntemleri}

En az müdahale ile diş hekimliği; (MINIMAL INTERVENTION DENTISTRY) çürük yönetimine, çürük risk değerlendirmesine, çürüğün erken önlenmesine ve hastalığın durdurulmasına odaklı olan modern tıbbi bir girişimdir. ${ }^{50}$ Merkezdeki görüş; diş çürüklerinin önlenmesi ve demineralize olmuş, kavitasyon göstermeyen mine ve dentinin en üst düzeyde korunmasıdır. ${ }^{19}$

Huth'a ${ }^{19}$ göre minimal invaziv tedaviler;

-Oral hijyen eğitimi,

-Florid kullanımı,

-Kimyasal plak kontrol ajanları,

-Koruyucu fissur örtücüler,

-Ozon.

Ozon, çürüklerin önlenmesinde kullanılan girişimsel olmayan bir tedavi yöntemi olmasının yanında var olan çürüklerin tedavisinde de kullanılır ${ }^{19}$. Ozon, ağız içerisindeki mikroorganizmalar üzerinde antimikrobiyal etkinlik gösterir mikroorganizma sayısını azaltır. ${ }^{10,18,19}$ Ozon, karbonhidratları, tükürük içerisinde ve çürük diş yüzeyinde bulunan demineralizasyona neden olan asitleri okside ederek ortamı alkalen hale getirir ve demineralizasyonu önler. Kavitasyon oluşmamış mine düzeyindeki çürük lezyonlarının içerisindeki biyomolekülleri okside ederek lezyonu koruyan protein tabakayı ortadan kaldırır, lezyon içerisindeki dentin kanallarını açık hale getirir. Tübüllere mineral yığıımı kolaylaşır. Kalsiyum ve fosfat iyonlarının lezyonun derinlerine ulaşabilmesini sağlayan bir temel hazırlar. Aktif lezyon inaktif hale gelir. Demineralizasyonremineralizasyon dengesi remineralizasyon yönüne doğru kayar. Remineralize olan diş yüzeylerinin de yeni asit saldırılarına karşı daha dayanıklı olduğu çeşitli çalışmalar tarafından bildirilmiştir. ${ }^{20}$

Ozonun demineralize dentin üzerinde de remineralizasyon etkisi olabileceği bazı çalışmalar tarafından bildirilmiştir. ${ }^{21,22}$ Inaba $^{21}$ başka bir oksidan olan sodyum hipokloritin demineralize dentin üzerindeki remineralizasyonu teşvik edici etkisi olduğunu yaptığı bir in vitro çalışma sonucu bildirmiştir. Ozon hipoklorite göre daha kuvvetli bir oksidan- dır. Baysan ${ }^{22}$ ozonun lezyondaki proteinleri uzaklaştır- dığını, lezyona kalsiyum ve fosfat iyonlarının geçişinin artığını ve böylece remineralizasyonun gerçekleştiğini yaptığı bir in vitro çalışmada bildirmiştir. Zaura ve arkadaşları $^{23}$ yaptıkları başka bir in vitro çalışmada ozonun demineralize dentinde remineralizasyon yapmadığını bildirmişlerdir.

\section{Başlangıç Cürükleri ve Ozon Tedavisi}

Ozon uygulamasının başlangıç çürüklerinde olumlu etkiye sahip olduğu çeşitli çalışmalar tarafından bildirilmiştir. Çalışmalarda; ozonun, başlangıç çürüklerindeki mevcut mikroorganizmaları ve ağız ortamındaki karyojenik bakterileri, bunların karbonhidrat fermentasyonu sonucu oluşturdukları asitleri okside ederek mikroorganizma sayısını ve demineralizasyonu azalttığı, dengeyi remineralizasyon yönüne kaydırdığı ve başlangıç çürük lezyonlarında remineralizasyon ve gerileme sağladığı bildirilmiştir ${ }^{20}$.

Abu Naba ${ }^{24}$ ozonun sealent uygulaması ile birlikte pit ve fissur çürüklerindeki etkinliğini ölçmek için randomize klinik bir çalışma yapmıştır. ECM (electronic caries monitor) ve DIAGNODENT ile ölçümler yapılmıştır. 1, 3, 6, 9, 12 aylık tüm kontrol seanslarında ozon uygulaması belirgin biçimde olumlu sonuçlar verdiği bildirilmiştir. Ayrıca bu çalışmada hastalara ozon hakkında anket yapılmıştır. Ozon tedavisinin klasik dental tedavilere kıyasla daha az anksiyete yarattığı hatta hastaların tedaviden memnun olduğu, tedavi için tekrar başvurabileceği ve yakınlarına önereceği sonuçları ortaya çıktığı bildirilmiştir.

Aynı çalışma grubu kavitasyon içeren pit ve fissur çürükleri üzerinde randomize klinik bir çalışma yapmış, test grubuna 10 saniye ozon uygulanmış diğer gruba tedavi uygulanmamış kontrol grubu olarak değerlendirilmiştir. 1, 3, 6 aylık kontrollerde ECM ve DIAGNODENT ölçümleri yapılmış saniyelik ozon uygulamasının çürükleri remineralize edebildiği ve alternatif bir tedavi olarak kullanılabileceğini bildirilmiştir. ${ }^{24}$

Atabek ve ark. ${ }^{25}$ yaptıkları bir çalışmada fissür çürüklerinde ozonun remineralize edici solüsyon ve hasta kiti ile birlikte kombine kullanımının etkinliğini değerlendirmişlerdir. Ozon uygulamasının remineralize edici solüsyonla ve özellikle ilave hasta kitiyle kullanımının başlangıç fissür çürüklerinin remineralizasyonunda ve tükürük streptococcus mutanslactobasillus seviyeleri üzerinde etkili olduğu saptan- 
mıştır. Sonuç olarak ozon uygulamaları sonrasında oluşan hipermineralize diş dokusunun yeni asit ataklarına daha dirençli bir yapı kazanacağını, ozon uygulamalarının mineral içeriği yüksek ajanlarla kombine kullanımının diş hekimliğinde invaziv olmayan yaklaşımların amacına hizmet edebileceğini ve yöntemin ağrısız, atravmatik, hızlı, hasta tarafından kabulünün yüksek olduğunu bildirmişlerdir.

Huth $^{26}$ yaptığı klinik çalışmada yüksek çürük riski olan bireylerin kavitasyon göstermeyen başlangıç çürüklerinde 40 saniyelik ozon uygulamasını test etmiştir. 3 aylık DIAGNODENT ile yapılan ölçümler sonucunda çürük lezyonlarında belirgin azalmalar izlenmiştir. Ancak tüm çalışma grubu değerlendirildiğinde istatiksel olarak anlamlı bir farklılık bulunamamıştır.

\section{Arayüz Cürrükleri ve Ozon Tedavisi}

Ozon tedavisi pit ve fissür çürüklerini etkilediği aynı mekanizmalar ile arayüz çürüklerinde de başarı sağlayabilir. Arayüz çürükleri oklüzal çürüklerin aksine radyografta izlenebilir. Çürüğün ilerleyiş hızına ve derinliğine göre tedavi yönteminin invaziv ya da noninvaziv olacağına karar verilir. Genel olarak yavaş ilerleyen kavitasyon göstermeyen çürükler mineyi ve dentin mine birleşim alanını içine alır. Bu tarz arayüz çürüklerinde ilk olarak non-invaziv tedaviler denenmelidir. Eğer lezyon dentini de içeriyorsa son karar hastanın çürük riski değerlendirilerek verilir. Kavitasyon izlenen arayüz çürüklerinde ise restorasyon zorunlu olduğu bildirilmişitir ${ }^{27}$. Arayüz çürüklerinde restorasyon öncesi ozon kullanımı kalan dentin dokusunu olumlu yönde etkiler yüzey sertliğini artırır. Aproksimal çürüklerde ozon tedavisinin çürük yüzeyi ulaşılabilir bir alanda olmadığı zaman uygulanmasında problemler oluşur. Air abrazyon ile ozonun birlikte kullanımı minimal invaziv bir yöntemdir ve bu sorunu çözebilir. Arayüz çürüklerinde air abrazyon ve ozonun birlikte kullanımı klasik yöntemlerle kıyaslayan çeşitli çalışmalar yapılmıştır ve air abrazyon ve ozonun birlikte kullanımının başarılı olduğu bildirilmiştir ${ }^{28}$.

Clifford $^{29}$; arka dişlerde, arayüz çürüklerinde air abrazyon, ozon ve seal yönteminin birlikte kullanılmasını değerlendiren klinik bir çalışma yapmıştır. Ozon uygulanan yüzeylerin 3 aylık kontrollerde remineralize olduğu ve sertleştiği izlenmiştir. Daimi restorasyon sonrasında 9. ayda yapılan kontrollerde ise ozon uygulanan dişlerin hiçbirinde semptom izlenmemiştir. Ayrıca çalışma sonucunda air abrazyon ve ozon yönteminin klasik yönteme göre zaman açısından daha avantajlı olduğu bildirilmiştir.

\section{Dentin Cürrükleri ve Ozon Tedavisi}

Dentin çürüklerinde de ozon tedavisi kulanılabilir. Yapılan çalışmalarda ozonun çürük dokusu kaldırıldıktan sonra kalan, sondla muayene edildiğinde köselemsi his veren dentinde remineralize edici etkisinin bulunduğu, bu dentinin sertliğini arttırdığı bildirilmiştir. 3,20

Bir klinik çalışmada tek yüzlü açık çürük yüzeylerinde ozonun çürük lezyonunun gerilemesi üzerine etkisi araştırımıştır. Tedaviyi kabul etmeyen 26 yaş arası çocuklarda mevcut olan çürükler ekskavatör ile köseleye benzer dokunma hissi alana kadar temizlenmiştir. Bir gruba ozon uygulanmış diğer grup kontrol grubu olarak bırakılmıştır. 2, 4, 6, 8 aylık kontrollerde yüzey sertliği değerlendirilmiş, DIAGNODENT ile ölçümler yapılmıştır. Kontrol grubunda DIAGNODENT ölçümleri artmış olsa da istatiksel olarak anlamlı bulunmamıştır. Ozon uygulanan grupta ise DIAGNODENT değerleri ortalama olarak \%13 azalmıştır. Ozon uygulanan grubun yüzey sertliğinin başlangıç ve kontrol grubuna göre belirgin oranda daha yüksek olduğu bulunmuştur. Kontrol grubunun hiçbir kontrol seansında yüzey sertliğinde anlamlı bir değişme izlenmemiştir. Anket sonucunda çocuklardaki korkunun ikinci seansta \%82, son seansa kadar ise $\% 93$ oranında azaldığı bildirilmiştir ${ }^{30}$.

\section{Kök Çürükleri ve Ozon Tedavisi}

Kök çürükleri de diğer çürükler gibi dental plak, besinsel karbonhidrat ve çürük riskine yatkın diş faktörlerinin birleşmesi ile oluşur. Ancak kök çürüğünün gerçekleşmesi için ayrıca kök yüzeyinin de açığa çıkmış olması gerekir. Streptococcus mutans, streptococcus sobribus ve laktobasillerin tükürük içerisindeki miktarı ve bu bakterilerin kök yüzeylerinden temizlenme sıklığı kök çürüklerinin gelişiminde önem teşkil etmektedir. Mine çürüklerinden farklı olarak kök yüzeyi çürüklerinde toplam plak florası ve hastanın oral hijyen derecesi çürüğün oluşumu ve gelişimi açısından daha önemlidir. Kök yüzey çürüklerinin tedavisi pahalı ve zaman alıcı işlemdir. Çok çeşitli restoratif materyaller kullanılmaktadır ancak bu tedavilerde de çok çeşitli başarısızlıklar yaşanmaktadır. Kök çürüklerinde ozon tedavisi de kullanılabilir. Kök çürükleri; ozon uygulamaları ile lezyonun mikrobiyal aktiviteye direnci artırılarak ve var olan mikrobiyal aktivite azaltılarak 
başarılı bir şekilde tedavi edilebilir ${ }^{31}$.

Baysan $^{32,33}$, primer kök çürükleri üzerinde ozonun etkinliği ile alakalı bir in vitro çalışma yapmıştır. Total bakteri sayısında da, . Streptococcus mutans ve streptococcus sobribus sayısında da belirgin azalmalar olduğunu bildirmiştir. Daha sonra in vitro çalışmasını klinik randomize bir çalışmaya uyarlamış ve kontroller sonucunda DIAGNODENT ve ECM ölçümlerinde ozon tedavisi uygulanan grupta belirgin olarak daha fazla remineralizasyon izlenmiştir.

Holmes ${ }^{34}$ yaptığı klinik randomize bir çalışmada kök çürük yüzeyleri üzerinde ozonun yüzey sertliğine (yumuşak, köselemsi, sert) etkisini değerlendirmiştir. 12 ay sonunda hastalarda ozon tedavisi yapılan dişlerin \%100'ünde çürük yüzeylerinin sertleştiğini, tedavi uygulanmayan kontrol grubunda ise \%37 vakada lezyonların daha da kötüleştiğini bildirmiştir.

\section{ART ve Ozonun Birlikte Kullanımı}

Atravmatik restoratif teknik çocuklarda ve yetişkinlerde kullanılan yerleşik bir tedavi yöntemidir. El aletlerinin yardımı ile çürüğün temizlenmesi ve adeziv bir materyal ile dişin restore edilmesi ilkesine dayanır. Minimal enstrümantasyon ve basit materyaller ile tedavi yapılır ve tedavi sonucu öngörülebilir. Ozondaki gelişmeler düşünülürse ART ile ozonun birlikte kullanılması ile başarı şansı arttırılabilir. Çeşitli çalışmalar çürük dokusunun tam olarak temizlenememesi durumunda yüksek floridli cam iyonomer kullanımı ile kalan bakterilerin inaktive olacağı, floritin kalan diş dokusuna yerleşebileceği ve dişin tamirinin mümkün olabileceğini bildirmiştir ${ }^{35}$.

Ozon; antimikrobiyal etkinliği, etkilenmiş diş yapılarında remineralizasyonu teşvik ettiği, adeziv materyallerin bağlantı kuvvetini etkilemediği için ART ile birlikte kullanıldığında başarı şansını arttırır ve restorasyonların ömrünü büyük ölçüde uzatabilir ${ }^{35}$.

Holmes $^{36}$, kök yüzey çürüklerinde ART ve ozonun birlikte kullanımı ile klasik yöntemi kıyaslayan randomize kontrollü klinik bir çalışma yapmıştır. Çalışmada ART ve ozonun dişin vitalitesine etkisi ve restorasyonun başarısı değerlendirilmiştir. Klasik yöntemlerle çürük temizliğinde iatrojenik nedenli perforasyonlar olabilir. Çalışma sırasında ART ve ozonun birlikte kullanıldığı hiçbir örnekte perforasyon oluşmamış, kontrol seanslarında semptom izlenmemiş ve yapılan tüm restorasyonlar estetik olarak başarılı bulunmuştur. Klasik yöntemin denendiği örneklerin $11^{\prime} \mathrm{i}$ işlem sırasında perfore olmuştur. Restore edilenlerin arasından 4 örneğe de 18 aylık kontrol sonucu kök kanal tedavisi gerekmiştir. Ayrıca ART ve ozonun birlikte kullanılmasının klasik tekniğe göre zaman açısından daha avantajlı olduğu bildirilmiştir.

\section{Ozonun Restoratif Materyallere Etkisi}

Ozonun çürüklerde kullanılması, araştırmacıları ozonun restoratif materyallere olası etkilerini araştırmaya yönelmiştir. Ozonun sık kullanılan restoratif materyallerin yüzey sertliğine ve mine/ dentinrestoratif materyal bağlanma kuvvetine etkisini değerlendiren çalışmalar mevcuttur. ${ }^{37-41}$

D.Campbell ${ }^{37}$, yaptığı bir in vitro çalışmada amalgam, cam iyonomer siman, kompomer, hibrit kompozit, akışkan kompozit, kompozit, rezin modifiye cam iyonomer siman üzerinde ozonun materyallerin yüzey setliğine etkisini değerlendirmiştir. Ozon uygulaması öncesi ve sonrasında yüzey sertliği ölçülmüş, rezin modifiye cam iyonomer siman haricinde tüm materyallerde yüzey sertliğinde istatistiksel olarak belirgin bir azalma izlenmiştir. Bu konunun tam değerlendirilebilmesi için klinik çalışmalar yapılması gerekmektedir. D.Campbell ${ }^{41}$, yaptığı başka bir in vitro çalışmada ozon tedavisinin kompozit rezinlerin mine ve dentine bağlanma kuvvetine etkisini değerlendirmiştir. Sonuç olarak ozonun bağlanma kuvvetine zarar verici bir etkisinin bulunmadığını bildirmiştir.

Marchesi ve arkadaşları ${ }^{38}$, gaz halindeki ozonun kavite dezenfeksiyonu sonrasında kompozitin mine ve dentine bağlanma kuvvetine etkisini değerlendirmiş ve gaz formundaki ozonun zarar verici bir etkisinin olmadığını bildirmişlerdir.

Garcia $^{39}$, ozonlu su ve ozon gazının dentin/ rezin bağlantı kuvvetine etkisini değerlendirmiş, iki ozon uygulama şeklinin de dentin/rezin bağlantı kuvvetine zarar verici bir etkisinin olmadığını bildirmiştir.

Kıvanç ve arkadaşları ${ }^{40}$, ND YAG lazer ve ozon uygulamasının fiber postların bağlanma kuvvetine etkisini değerlendirmişler ve ND YAG lazer ve ozon uygulamasının fiber postların bağlanma kuvvetine zarar verici bir etkisinin olmadığını bildirmişlerdir.

\section{OZON VE HİPERSENSİTIF DENTÍN TEDAVİsí}

Mine kaybı, dentin kaybı, dişeti çekilmesi gibi çok çeşitli etkenler ile dentin tübüllerinin açığa çıkmasına neden olur ve bunun sonucunda hassasiyet 
semptomları izlenebilir. Dentin hassasiyeti ile ilgili en geniş kabul gören teori, Brännström ve Aström tarafından ortaya konan hidrodinamik teoridir. Her türlü uyarı dentin tübülleri içerisindeki dentin sıvısının hidrodinamik hareketi ile pulpaya iletilmektedir. Isısal, fiziksel veya ozmotik değişimler dentin sıvıSı hacminin değişimine veya hareketine neden olarak bir basınç reseptörünü uyarır ve bu da sinirler üzerinde impuls oluşturur. Uyaranın cinsine göre (termal, ozmotik, elektriksel, kimyasal) dentin tübülleri içerisindeki sıvı ya pulpa yönünde ya da dışarı doğru hareke etmekte ve pulpaya iletilmektedir. Sebebi belirlenip elimine edildikten sonra tedavi uygulanır. Hipersensitivitede; tedavi yöntemlerinin amacı açık dentin tübüllerinin kapatılması ya da interdental sinir aktivitesinin azaltılmasıdır. ${ }^{24,42,43}$

Tedavi Yöntemleri ${ }^{42}$;

1) Hassasiyet giderici macunlar, gargaralar, yumuşak kıllı fırçalar,

2) Hasasiyet giderici ajanlar,

3 Cam iyonomer, rezin modifiye cam iyonomerler/kompomerler, adeziv rezin primer ve adeziv rezin bonding sistemler,

4) Lazer,

5) Periodontal plastik cerrahidir.

Çeşitli uyaranlara bağlı olarak dentin tübüllerindeki dentin sıvısının hareketin yanı sıra, bakteriler de açık dentin tübüllerini etkileyebilir. Bu rahatsızlığın ozon tedavisi ile çözülebileceği düşünülmektedir. Ozon açık tübüllere penetre olabilir, bakteri kontaminasyonunu ortadan kaldırabilir ve tübülleri tükürükte mevcut olan minerallerin girebilmesi için hazırlayabilir. ${ }^{24}$

\section{OZON VE ÇATLAK DİŞ SENDROMU}

Çatlak diş, sendromu; vital posterior dişin dentin tabakasında olan ve bazen pulpaya da ulaşan çatlağı ifade eder. Çatlak diş, sendromunda en sık karşılaşılan şikâyet çiğneme sırasında ağrı olmakla birlikte değişik klinik tablolar görülebilir. Çatlak diş sendromu hastaIarın yaşam kalitesini çok etkileyen bir rahatsızıktır ${ }^{44}$. Modern diş hekimliğinde ozon kullanımının bu rahatsızlığın tedavisinde başarılı olabileceği düşünülmektedir. Ozon; dentin hassasiyeti tedavisindeki aynı mekanizma ile çatlak diş sendromunda da başarılı olabilir $^{27}$.
Delay ve Holmes ${ }^{45}$, ozon uygulamasının; çatlak diş sendromu rahatsızlığı olan hastalarının semptomlarında azalma sağladığını bildirmiştir. Ozonun florlama ile birlikte uygulanmasının da yararlı olabileceği düşünülmektedir.

Ozon jeneratörü üreticilerinden Medozon; cihazlarının çatlak diş sendromunda çatlak alana 60120 saniye uygulanmasının ardından uzun ömürlü restoratif materyalin kullanılabileceğini, tedavinin başarı sağlayabileceğini iddia etmektedir ${ }^{27}$.

\section{OZON VE AĞARTMA TEDAVİSI}

Koruyucu diş, hekimliği hizmetlerinin giderek yaygınlaşması ve teknolojik gelişmelerin kullanılan materyallere yansıması, diş, hekimliği uygulamalarında büyük değişimlerin yaşanmasına yol açmıştır. Bu süreçle birlikte hastaların talepleri, kalıcı ve fonksiyonel tedavilerin yanı sıra estetik tedavilere yönelmiş, diş hekimliğinde ağartma tedavisi popüler hale gelmiştir ${ }^{46}$. Addy, renklenmeleri içsel ve dışsal olarak sınıflandırmıştır. Dışsal renklenmeler renklendirici etkenlerin diş yüzeyine akümülasyonu ile gerçekleşir. Dışsal renklenmelerde öncelikle mekanik temizlik, parlatma, profesyonel proflaksi işlemleri uygulanır, başarılı olunmaz ise kimyasallar kullanılarak ağartma tedavisi yapılır. İçsel renklenmelerde renklendirici etkenler dişin kendi yapısından kaynaklıdır ve bu renklenmelerin tek tedaisi kimyasal yöntemlerle olabilir ${ }^{47}$. Diş hekimliğinde ağartma tedavilerinde okside edici ajanlar kullanılmaktadır. Bunlar; karbamid peroksit, hidrojen peroksit ve ozondur. Bu kimyasalların mekanizması renklen me yaratan etkenlerin oksidasyon ile uzaklaştırılmasıdır.

Ozon, güçü okside edici özeliklere sahip bir moleküldür. Bu özellik sayesinde ozon ağartma tedavilerinde başarılı bir şekilde kullanılabilir. Holmes ${ }^{48}$, yaptığı in vitro çalışma sonucunda ozonun dışsal renklenmelere neden olan komponentleri okside ettiğini ve ağartma tedavisinde başarıyla kullanılabileceğini bildirmiştir.

Ağartma; gaz ozon ile özel cihazlarla tüm çeneye uygulanma şeklinde yapılmaktadır. Bu şekilde klasik ağartma yöntemlerine kıyasla tedavi daha kısa sürmektedir. Klasik yöntemlerde dişler ajanla kaplanmadan önce rubber dam takılması ya da özel ajanlar yardımıyla diş etinin zarar görmemesi için izole edilmesi gerekmektedir. İzolasyonda eksiklik olduğu takdirde kimyasal ajanlar diş etine zarar verebilir, 
hastaların tedavi süreci memnuniyetsiz geçebilir. Ayrıca ajanla kaplanmış dişe uygulanan ışık neticesinde ISI artışı da hastaya rahatsızıı veren bir durumdur. Ozon ile ağartmada bu tip sıkıntılar yaşanmaz. Herhangi bir ek ilave işlem gerektirmeksizin ozon uygulaması ile ağartma yapılabilir ve hastanın konforunu etkileyebilecek bir durum söz konusu değildir. Diş etlerine zarar vermenin aksine güçü dezenfektan etkinliğinden dolayı var olan diş eti hastalıkları için tedavi edici etki gösterir ${ }^{49}$.

Başlangıç çürüklerinde ozon tedavisinin remineralize edici etkisi vardır. Ağartma sırasında var olan başlangıç çürüklerinin de remineralize olması teşvik edilir.

Ozonun rezinler ile mine-dentin bağlantı kuvvetine zarar verici bir etkisi olmadığı çeşitli çalışmalar tarafından bildirilmiştir. ${ }^{37-40,50,51}$ Bu nedenle ağartmayı takiben rezin restorasyonlar uygulanabilir.

Klasik ağartma yöntemleri sonrası diş hassasiyeti hastaları oldukça rahatsız eden ve sık görülen bir sorundur. Ozon ile ağartma sonrasında bu durum söz konusu olmaz hatta hasta da dentin hipersensitivitesi mevcut ise semptomlarda da azalma bile sağlanabilir ${ }^{49}$.

Tüm çene ozonlu ağartma sistemleri ile dişlerin lingual yüzeylerinde de ağartma sağlanabiliir ${ }^{52}$.

Gelişmiş ozon ile ağartma sistemlerinden Ozonytron firması; ozon cihazına bağlı ozon gazını tüm çeneye bir anda uygulamayı sağlayan kaşıklar üretmişlerdir. Bu kaşıklar ile tüm çene ağartma tedavisi yapılabilir. Tüm çene ozonlu ağartma sistemleri ile dişlerin lingual yüzeylerinde de ağartma sağlanabilir. Firmanın ağartma ürününde kaşıkların çeşitli boyutları mevcuttur. Ağartmanın başarılı olabilmesi için kaşıkların çenelere tam adaptasyonu gerekmektedir. Kaşıklar ile her hastada tam adaptasyon sağlanamayabilir ve bu nedenle tedavide başarısızık olabilir. Ayrıca hastalar kaşıktan rahatsızlık duyabilirler. ${ }^{52}$

Abu Naba'a ve ark. ${ }^{24}$ derlemelerinde İngiltere ve İspanya'da yapılan tüm çene ozon ağartma sistemleriyle yapılan çalışmalarda; kısa süreli uygulamalarda başarılı sonuçlar elde edildiğini, Küba'da ise ozonlu yağların ağartmada kullanımı ile ilgili çeşitli çalışmalar yapıldığını ve kök kanal tedavili dişlere ozon yağı uygulandığııı ve olumlu sonuçlar alındığını bildirmişlerdir. Ozon ile ağartmanın içsel renklenmelerde de kullanılabileceği düşünülmektedir. Tessier ve arkadaşları ${ }^{50}$ tarafindan, keserlerin tetrasiklin renklen- mesinde ozon ile ağartmanın etkinliğini değerlendiren bir hayvan çalışması yapılmıştır. Çalışma sonucunda keserlerde tetrasiklin renklenmesinde ozon ile ağartmanın başarılı olduğu bildirilmiştir.

\section{SONUÇ}

Restoratif dişhekimliğinde ozon tedavisi, yapılan çalışmalar sonucunda birçok alanda başarıı olarak nitelendirilebilir. Ozon tedavileri henüz klinik olarak yaygın bir biçimde kullanılmamaktadır. Literatürler incelendiğinde özellikle ağartma, diş hassasiyeti tedavisi ve çatlak diş sendromunda kullanımı oldukça nadirdir. Ozonun etkilerinin daha rasyonel biçimde değerlendirilebilmesi ve klinik kullanımının arttırılabilmesi için konu hakkında daha fazla araştırma ve klinik randomize çalışma yapılmasına gereksinim vardır.

\section{KAYNAKLAR}

1. Saini $R$, Ozone therapy in dentistry: A strategic review, J Nat Sci Biol Med. 2011;2:151-3.

2. Grootveld M, Baysan A, Sidiiqui N, Sim J, Silwood C, Lynch E. History of the clinical applications of ozone The Revolution in Dentistry. 1 st ed. London: Quintessence Publishing Co. Ltd, 2004 73-115.

3. Azarpazhooha A, Limeback $H$; The application of ozone in dentistry: A systematic review of literature. Journal of Dentistry 2008; 36: 104-16.

4. Özler M, Öter Ş, Korkmaz A. The Use of Ozone Gas for Medical Purposes. TAF Preventive Medical Bulletin 2009; 8:59-64.

5. Bocci V. Ozone as Janus: this controversial gas can be either toxic or medically useful. Mediators Inflamm. 2004; 13: 3-11.

6. Bocci V. Oxygen-ozone therapy: a critical evaluation. Springer, 2002, 1-8.

7. Seidler $V$, Linetskiy I, Hubalkova $H$, Staňkova $H$, Šmucler R, Mazanek J. Ozone and Its Usage in General Medicine and Dentistry. A Review Article. Prague Medical Report. 2008; 109: 5-13.

8. Muller P, Guggenheim B, Schmidlin PR. Efficacy of gasiform ozone and photodynamic therapy on a multispecies oral biofilm invitro. European Journal of Oral Sciences 2007;115: 77-80. 
9. Nagayoshi M, Kitamura C, Fukuizumi T, Nishihara T, Terashita M. Antimicrobial effect of ozonated water on bacteria invading dentinal tubules. Journal of Endodontics 2004; 30: 778-81.

10. Gupta G, Mansi B Ozone therapy in periodontics, J.Med. Life 2012; 22;5: 59-67.

11. Babacan A, Ozon, Ozonterapi ve Klinik Kullanımı, Turkiye Klinikleri J Med Sci 2008;28:245-7.

12. Baysan A, Whiley RA, Lynch E. Antimicrobial effect of novel ozone generating device on microorganisms associated with primary root carious lesions in vitro. Caries Research 2000; 498: 34.

13. Srikanth A, Sathish M, Harsha AVS, Application of ozone in the treatment of periodontal disease Journal of Pharmacy \& Bioallied Sciences,Medknow Publications 2013; 5: 89-94.

14. Dinç G, Kavite Dezenfektanlarının Antibakteriyel Özellikleri, Bağlanma Dayanımı ve Mikrosızıntı Üzerine Etkileri. Atatürk Üniv Diş Hek Fak Derg 2012, 6; 66-75

15. Matsumura K, Hyon SH, Nakajima N, Iwata $H$, Watazu A, Tsutsumi S. Surface Medication of polyethylene-co-vinyl alcohol hydroxyapatite immobilization and control of periodontal ligament cells differentiation. Biomaterials 2004; 25:481724.

16. Nogales CG, Ferrari PH, Kantorovich EO, LegwMarques J. Ozone therapy in medicine and dentistry. J Contemp Dental Pract. 2008; 9 :1-9

17. Krammer F. Ozone in the dental practice. Medical applications of ozone. Norwalk, CT: International ozone association, Pan American committe 1983; 258-65

18. Deepa Thaman, Pooja Sood; Ozone Therapy in Conservative Dentistry and Endodontics: An Overview; Indian J Stomatol 2012; 3:165-9

19. Huth K.C Hickel R. The Role of Ozone in "Minimal Intervention Dentistry" ,The Revolution in Dentistry. 1 st ed. London: 2004 Quintessence Publishing Co. Ltd, p.117-124

20. Abu-Naba'a L., Lynch E. Clinical Management of Pit and Fissure Caries Using Ozone and Some Research Results; 1 st ed. London: Quintessence Publishing Co. Ltd, 2004
21. Inaba D, Ruben J, Takagi O, Arends J: Effect of sodium hypochlorite treatment on demineralization of human root dentine in vitro. Caries Res 1996; 30: 218-24.

22. Baysan A, Lynch E: Effect of ozone on the oral microbiota and clinical severity of primary root caries. Am J Dent 2004;17:56-60.

23. Zaura E, Buijs MJ, ten Cate JM; Effects of ozone and sodium hypochlorite on caries-like lesions in dentin. Caries Res. 2007;41:489-92.

24. AbuNaba'a L, AlShorman H, Holmes J, Peterson L,Tagami J, Lynch E. The Revolution in Dentistry. 1 st ed. London: Quintessence Publishing Co. Ltd, 2004 p.73-115.

25. Atabek D, Oztas N. Effectiveness of Ozone with or without the Additional Use of Remineralizing Solution on Non-Cavitated Fissure Carious Lesions in Permanent Molars. Eur J Dent. 2011;5:393-9.

26. Huth KC, Paschos E, Brand K, Hickel R. Effect of ozone on non-cavitated fissure carious lesions in permanent molars: a controlled prospective clinical study. American Journal of Dentistry 2005; 18: 223-8.

27. Deepa Thaman, Pooja Sood; Ozone Therapy in Conservative Dentistry and Endodontics: An Overview, Indian J Stomatol 2012;3:165-9.

28. Clifford C, Holmes H, Lynch E. The Revolution in Dentistry. 1 st ed. London: 2004 Quintessence Publishing Co. Ltd, p. 191-6.

29. Clifford CPS. Reversal of Caries Using Airbrasion and Ozone-Nine Month Results. J Dent Res;. 82nd General Session of the IADR, 2004 Abstract; 3467

30. Dahnhardt JE,Jaeggi T, Lussi A. Treating open carious lesions in anxious children with ozone: a prospective controlled clinical study. American Journal of Dentistry 2006; 19: 267-70.

31. Baysan A, Lynch E., Antimicrobial Effects of Ozone on Caries, The Revolution in Dentistry. 1 st ed. London: Quintessence Publishing Co. Ltd, p. 2004 173-80.

32. Baysan A, Whiley RA, Lynch E. Antimicrobial effect of a novel ozone-generating device on microorganisms associated with primary root carious lesions in vitro. Caries Research 2000; 34: 498501. 
33. Baysan A., Lynch E. Management of primary root caries using ozone; The First Pan European Festival of Oral Sciences, 2002 Abstract; 195.

34. Holmes J. Clinical reversal of root caries using ozone, double-blind, controlled 18-month trial. Gerodontology 2003;20:106-14.

35. Holmes J, Lynch E. The Revolution in Dentistry. 1 st ed. London: 2004 Quintessence Publishing Co. Ltd, p. 187-90.

36. Holmes J. Restoration of ART and Ozone treated primary root carious lesions. J Dent Res, 82nd General Session of the IADR, 2004. Abstract; 2004d

37. Campbell D, Cunningham L,Hussey D, Armstrong C, Teretty K, Lynch E. The effect of ozone on the bond strenghts and surface hardness of some commonly used restorative materials in dental practice Study 1 The Revolution in Dentistry. 1 st ed. London: 2004 Quintessence Publishing Co. Ltd, Part 1. 197-8.

38. Marchesi G, Petris LC, Navarra CO, Locatelli R, Di Lenarda R, Breschi L, Cadenaro Effect of ozone application on the immediate shear bond strength and microleakage of dental sealants. Pediatr Dent 2012;34:284-8.

39. Garcia EJ, Serrano AP, Urruchi WI, Deboni MC, Reis $A$, Grande $R H$, Loguercio $A D$. Influence of ozone gas and ozonated water application to dentin and bonded interfaces on resin-dentin bond strength.J Adhes Dent 2012;14:363-70.

40. Kıvanç BH, Arısu HD, Ozcan S, Görgül G, Alaçam T. The effect of the application of gaseous ozone and ND:YAG laser on glass-fibre post bond strength. Aust Endod J. 2012;38:118-23.

41. Campbell D, Cunningham L,Hussey D, Armstrong C, Teretty K, Lynch E. The effect of ozone on the bond strenghts and surface hardness of some commonly used restorative materials in dental practice Study 2 The Revolution in Dentistry. 1 st ed. London: 2004 Quintessence Publishing Co. Ltd, Part 1. 197-8.

42. Yilmaz H G, Bayindir $H$, Cengiz $E$, Berberoğlu A, Dentin hypersensitivity and treatment methods. Cumhuriyet Univ Diş Hek Fak Derg 2012;15:71-82.

43. Attar N, Korkmaz Y, Dentin Aşırı Hassasiyeti Hacettepe Univ Diş Hek Fak Derg 2006;30: 83-91.
44. Çağırankaya L.B, Erbudak H.Ö, Akçiçek G. Çatlak Diş Sendromu. Hacettepe Univ. Diş Hek Fak Derg 2008; 32: 25-9.

45. Holmes J., Daley T., Sensitivity \& Cracked Teeth Treatment with Ozone. 2003 Erişim: 20 Ocak 2014 Ağ Sitesi; http://www.the-o-zone.cc/ HTMLOzoneF/ ch36.html,

46. Koruk D.C, Kırzıoğlu Z, Çocuklar ve Gençlerde Diş Beyazlatma İşlemlerine Yaklaşım. Atatürk Univ Diş Hek Fak Derg 2010; 3:44-53

47. Bazzi J.Z, Bindo M.J.F, Rached R.N, Mazur R.F, Vieira S, Souza E.M, The effect of athomebleaching and toothbrushing on removal of coffee and cigarette smoke stains and color stability of enamel, Journal of American Dental Association 2012;143:1-7.

48. Holmes J, Grootveld M, Smith C, Claxson AWD, Lynch E. Bleaching of Components Responsible for Extrinsic Tooth Discoloration by Ozone. 2003 AADR Abstract; 615

49. Holmes J, Daley T, Tooth Bleaching or Tooth Whitening. 2006 Erişim: 20 Ocak 2014, Ağ Sitesi; http://www.the-o-zone.cc/HTMLOzoneF/ ch35.html.

50. Tessier J, Rodriguez PN, Lifshitz F, Friedman SM, Lanata EJ.; The use of ozone to lighten teeth. An experimental study. Acta Odontol Latinoam 2010;23:84-9.

51. Walsh $\sqcup$, Brostek AM.Minimum intervention dentistry principles and objectives. Aust Dent J 2013 Jun;5:3-16.

52. Ozonytron Medikal Ozon Cihazları Erişim: 20 Ocak 2014, http://www.ozonytron.com/ en/ support/ media\#
Yazışma Adresi:
Dt. Gizem BOZTAS
Gazi Üniversitesi Diş Hekimliği Fakültesi
Diş Hastalıkları ve Tedavisi Anabilim Dalı
Yukarıbahçelievler Mah. 71.sk
Telefon: 05388640063
e-mail: Boztasgizem@hotmail.com 